\title{
EVALUASI IMPLEMENTASI DESAIN PENDIDIKAN KARAKTER BERBASIS PENDEKATAN HUMANISTIK
}

\author{
Musyarrafah Sulaiman Kurdi \\ Universitas Islam Negeri Antasari Banjarmasin \\ Jl. A. Yani No.KM. 4,5, Kebun Bunga, Kota Banjarmasin, Kalimatan Selatan 70235 \\ email: syarrakurdi@gmail.com
}

\begin{abstract}
The purpose of this study is to provide an illustration of the implementation resultof the learning design of character education courses based on a humanistic approach. This approach is used in order to provide atmospheric process of learning activities by providing stimulus to students as subjects in the learning process to acquire skills, knowledge, values and attitudes that are able to bring self-awareness as a person. Previously, the researcher has conducted development research to produce design of character education course based on humanistic approach. In this study, the research method used was a survey, in which researcher cited describing the results of the implementation of the learning process in the character education course based on a humanistic approach at UIN Antasari Banjarmasin in 2017 majoring in Islamic Madrasah Teacher Education, with 72 samples. Based on the results of the study, it is known that the design of character education courses based on the humanistic approach that has been designed previously, it is known that in 5 times learning processes, $75 \%$ of students feel that they have experienced the development of their inner values, $80 \%$ feel that each of them knows themselves more deeply than the past, and $87 \%$ felt that they had a clearer purpose in life, and $89 \%$ said that their inner potential could be more explored and more deep after do sequence of value project and activities. In general, there is an increase values and attitudes in students by $40 \%$, to $75 \%$ $-89 \%$, where previously only at the percentage of $35-63 \%$.
\end{abstract}

Keywords: Character Education, Humanistic Approach, Department of Islamic Elementary School Teacher Education

\begin{abstract}
Abstrak
Tujuan penelitian ini adalah untuk memberikan ilustrasi hasil imeplementasi dari desain pembelajaran mata kuliah pendidikan karakter berbasis pendekatan humanistik. Pendekatan ini digunakan dalam rangka menyediakan atmospher proses kegiatan belajar dengan mmeberikan stimulus kepada mahasiswa sebagai subjek dalam proses pembelajaran untuk memperoleh keterampilan, pengetahuan, nilai dan sikap yang mampu membawa perubhan kesadaraan diri sebagai pribadi. Sebelumnya peneliti telah mengadakan penelitian research and development untuk menghasilkan desain perkuliahan pendidikan karakter berbasis pendekatan humanistik. Dalam penelitian kali ini, metode penelitian yang digunakan adalah survey, di mana peneliti mencoa menggambarkan hasil hasil implementasi proses pembelajaran dalam mata kuliah pendidikan karakter berbasis pendekatan humanistik di UIN Antasari Banjarmasin tahun 2016-2017 di jurusan Pendidikan Guru Madrasah Ibtidaiayah, dengan 72 sampel. Berdasarkan hasil penelitian diketahui dengan desain perkuliahan pendidikan karakter berbasis pendekatan humanistik yang telah dirancanng sebelumnya, diketahui bahwa dalam 16 kali proses pemelajaran, 75\% mahasiswa merasa telah mengalami perkembangan nilai dalam dirinya,
\end{abstract}


80\% merasa bahwa masisng-masing dirinya mengenal diri mereka sendiri lebih dalam dari sebelumnya, dan 87\% merasa bahwa mereka memiliki tujuan hidup yang lebih jelas, dan 89\% menyatakan bahwa potensi di dalam dirinya lebih bisa dieksporasi lebih dalam setelah ada kegiatan project nilai. Secara general, ada peningkatan nilai dan sikap berbasis humanistik dalam diri mahasiswa sebesar 40\%, menjadi 75\%-89\%, di mana sebelumnya hanya berada pada nilai persetase $35-63 \%$.

Kata kunci: Pendidikan Karakter, Pendekatan Humanistik, Jurusan Pendidikan Guru Madrasah Ibtidaiyah

\section{Pendahuluan}

"True education does not consist merely in the acquiring of a few facts of science, history, literature, or art, but in the development of character." - David O. McKay. Proses pembentukannilai dalam diriseseorang tidak bisa dilepaskan dari proses belajar, yakni bagian yang paling penting dan memiliki peranan besar dalam proses perkembangan diri seseorang. Belajar dan mengajar, dalam arti sebuah proses, merupakan dua unsur yang tidak bisa terpisahkan. Belajar dan mengajar adalah dua kegiatan yang tunggal tapi memang memiliki makna yang berbeda. Keduanya adalah dua peristiwa yang berbeda akan tetapi keduanya memiliki hubungan yang sangat erat sekali. ${ }^{1}$ Kedua proses ini diibaratkan seperti halnya dua sisi koin yang saling menempel dan terikat satu sama lain. mengajar adalah kegiatan menyediakan kondisi yang merangsang serta mangarahkan kegiatan belajar siswa/subjek belajar untuk memperoleh pengetahuan, keterampilan, nilai dan sikap yang dapat membawa perubahan serta kesadaran diri sebagai pribadi. Kegiatan ini juga meliputi usaha mengorganisasi lingkungan sehingga menciptakan kondisi belajar bagi siswa. ${ }^{2}$

Mengajar, dalam kaitannya menumbuhkembangkan karakter, merupakan proses membimbing kegiatan, di mana peserta didik melakukan tindakan real selama berlangsugnya aktivitas belajar, guna menumuhkan nilai-nilai yang ada dalam

\footnotetext{
${ }^{1}$ Oemar Hamalik, Proses Belajar Mengajar, 6 ed. (Jakarta: Bumi Aksara, 2007), 44.

2 Oemar Hamalik, 48.
}

diri peserta didik. Oleh karenanya penting bagi seorang pendidik untuk memberikan bimbingan dan penyediaan lingkungan belajar yang baik dan tepat bagi peserta didiknya. Hampir seluruh pakar pendidikan mencoba merumuskan dan mengembangkan rumusan terjemahan dari aktivitas belajar yang mampu mengembangkan potensipotensi terbesar yang dimiliki peserta didik. Tidak heran jika berbagai kegiatan belajar ditawarkan untuk memberikan solusi dalam menumbuhkembangkan karakter peserta didik.

Idealnya, seorang guru dapat mengembangkan unsur-unsur muatan nilai bagi peserta didik dalam proses pemelajaran. Guru melihat dari semua sudut pendidikan, seperti makna belajar itu sendiri, proses pembelajaran yang diselenggarakan, memperhatikan hasil belajar peserta didik, mencoba menemukan gaya dan ciri khas belajar setiap peserta didiknya. Mereka juga perlu memperhatikan kemungkinan faktor-faktor yang mempengaruhi proses pembelajaran, pemberian keteladanan, dan higga memperhatika aspek psikologi belajara peserta didik, seperti motivasi dan sikap belajar. Semua unsur ini telah dijadikan topik pembahasan dalam perkembangan psikologi belajar dan teori-teori pendidikan, hingga bermunculan lah berbagai macam aliran psikologi.

Dalam sejarah perkembangan psikologi sudah dikenal berbagai macam aliran psikologi. Tiap aliran memiliki pandangan sendiri-sendiri tentang proses belajar. Pandangan- pandangan tersebut 
pada umumnya memiliki beberapa perbedaan mendasar satu sama lain dengan dilandasi alasan masing- masing. Dalam perkembangannya, ada beberapa aliran psikologi yang memberi makna dan arti tersendiri mengenai teori belajar, salah satu diantaranya adalah teori belajar aliran humanisme, yang memandang bahwa belajar bukan sekedar pengembangan kualitas kognitif saja, melainkan juga sebuah proses yang terjadi dalam diri individu yang melibatkan domain kognitif, afektif dan psikomotorik. Ini artinya, ketiga elemen ini saling menunjang satu sama lain, ketiganyamemilki keterkaitan dalam interaksi satu sama lain selama proses pembelajaran. Belajar dalam teori humanis ini berarti diartikan sebagai suatu perubahan tingkah-laku karena hasil dari pengalaman yang diperolehyg tidakhanya mengandalkan pegetahuan semata. Ini sejalan dengan makna belajar dalam teori Morgan, dalam bukunya yang berjudul Introduction to Psychology, menerjemahkan proses belajar sebagai setiap perubahan yang relatif menetap dalam tingkah laku yang terjadi sebagai suatu hasil dari latihan atau pengalaman.$^{3}$ Ini juga dapat diartikan bahwa ada beberapa hal yang harus mendapat perhatian pada diri manusia itu sendiri, yakni sisi kognitif, afektif dan psikomotor yang ditekankan oleh penganut paham teori humanistic.

Pada mulanya teori ini muncul sebagai bentuk ketidaksetujuan pada dua pandangan psikologi lainnya mengenai tingkah laku manusia, yaitu psikoanalisis dan behaviouristik. Psikoanalisis dipandang terlalu menunjukkan pesimisme suram serta keputusasaan, sedangkan behavioristik dipandang terlalu kaku, mekanistik, statis, pasif, dan teralalu penurut dalam menggambarkan manusia hanyalah sebatas sosok yang hidup dan bertindak layaknya

${ }^{3}$ M. Ngalim Purwanto, Psikologi Pendidikan, 16 ed. (Bandung: Remaja Rosdakarya, 2000), 84. robot. ${ }^{4}$ Teori belajar humanistik, yang dipelopori oleh Abraham Maslow ini, mencoba untuk mengkritisi teori Freud; behaviouristic. Menurut pandangan teori ini yang terpenting dalam melihat manusia adalah potensi yang dimilikinya. Teori pembelajaran ini komprehensif dalam memberikan pengembangan diri seseorang dan sanagt tepat diterapkan ke dalam proses perkuliahan, khususnya pada mata kuliah yang menuntut adanya penguatan penguasaan materi dan aplikasi nilai-nilai dalam kehidupan.

UIN Antasari Banjarmasin, dalam struktur kurikulumnya menyelenggarakan perkuliahan pedidikan untuk calon guru, mahasiswa Pendidikan Guru Madrasah Ibtidaiyah pada Fakultas tarbiyah dan Keguruan. Mata Kuliah ini membahas secara mendalam konsep dan aplikasi pendidikan karakter. Materi dalam mata kuliah ini pada dasarnya adalah konsep-konsep teoritis dan praktis pelaksanaan pendidikan karakter di sekolah termasuk didalamnya bagaimana upaya mengembangkan karakter mahasiswa (sesuai visi misi UIN Antasari: Kompetitif, Unggul, dan Berakhlak). Isi pokok mata kuliah ini meliputi: (1) konsep dasar karakter dan pendidikan karakter, (2) konsep dasar dan pola pengembangan pendidikan karakter dalam proses pembelajaran, (3) konsep dasar dan pola pengembangan pendidikan karakter di sekolah, (4) konsep dasar dan pola pengembangan pendidikan karakter di masyarakat, dan (6) konsep dasar dan pola pengembangan penilaian otentik karakter. Dengan mempelajari mata kuliah ini, mahasiswa diharapkan mampu memahami isu terbaru dalam bidang pembelajaran di SD khususnya tentang pendidikan karakter sehingga kelak mampu bekerja di lingkungan pesekolahan dengan baik dan berkarakter serta mampu membina karakter siswa. Oleh karenanya sangat

${ }^{4}$ Baharuddin, Teori Belajar dan Pembelajaran, $\mathrm{V}$ (Yogyakarta: Ar-Ruzz Media, 2010), 141. 
penting untuk pelaksanaan pembelajaran berbasis pendekatan yang menekankan tiga aspek, kognitif, afektif, dan psikomotor, yakni humanistik.

\section{Tujuan Penelitian}

Tujuan penelitian ini adalah untuk mengilustrasikan hasil dari desain pembelajaran pada mata kuliah pendidikan karakter berbasis pendekatan humanistik di Universitas Islam Antasari Banjarmasin Jurusan Pendidikan Guru Madarasah Ibtidaiyah pada mata kuliah Pendidikan Karakter. Sebelumnya, pembelajaran telah didesain menggunakan pendekatan research and development untuk menghasilkan sebuah desain proses pembelajaran.

\section{Pendekatan Pembelajaran Humanistik}

Teori belajar humanistik, yang dipelopori oleh Abraham Maslow (1984), mencoba untuk mengkritisi teori Freud; behaviouristic, bagian terpenting dalam melihat manusia adalah potensi yang dimilikinya. ${ }^{5}$ Teori ini lebih melihat pada sisi perkembangan kepribadian manusia daripada berfokus pada "ketidaknormalan" atau "sakit" seperti yang dilihat oleh Frued dengan teorinya psikoanalisa. Pendekatan humanistik lebih menekankan melihat pada bagaimana manusia membangun dirinya untuk melakukan hal- hal yang positif, Kemampuan bertindak positif ini yang disebut sebagai potensi manusia dan para pendidik yang beraliran humanistik biasanya memfokuskan pengajarannya pada pembangunan kemampuan positif ini. ${ }^{6}$ Artinya kemampuan disini erat kaitannya dengan pengembangan emosi positif yang terdapat dalam domain afektif, misalnya keterampilan membangun dan mejaga relasi yang hangat dengan orang lain, bagaimana

5 Abraham H. Maslow, Motivasi Dan Keperibadian (Jakarta: Pustaka Binoman Pressido, 1984).

6 Iskandar, Psikologi Pendidikan (Sebuah Orientasi Baru) (Ciputat: Gaung Persada Press, 2009), 114. mengajarkan kepercayaan, penerimaan, kesadaran, memahami perasaan orang lain, kejujuran interpersonal, dan pengetahuan interpersonal lainnya. ${ }^{7}$ Intinya adalah meningkatkan kualitas ketrampilan interpersonal dalam kehidupan sehari- hari.

Selain menitikberatkan pada hubungan interpersonal, para pendidikan yang beraliran humanistik juga mencoba untuk membuat pembelajaran yang membantupesertadidikuntukmeningkatkan kemampuan dalam membuat, berimajinasi, mempunyai pengalaman, berintuisi, merasakan, dan berfantasi. ${ }^{8}$ Pendidikan dengan teori humanistik mencoba untuk melihat dalam spectrum yang luas mengenai perilaku manusia. "Berapa banyak hal yang bisa dilakukan manusia? Dan bagaimana aku bisa membantu mereka untukmelakukanhalhal tersebut dengan lebih baik?". ${ }^{9}$ Oleh sebab itu dapat disimpulkan bahwa pendekatan humanistik ini lebih menekankan dan mengedepankan pentingnya emosi dalam dunia pendidikan, dan emosi merupakan karakteristik yang sangat kuat yang Nampak dari para pendidik beraliran humanistik. Jadi, hal ini sesuai dengan yang telah penulis singgung di latar belakang makalah ini, bahwa belajar bukan sekedar pengembangan kualitas kognitif saja, melainkan juga sebuah proses yang terjadi dalam diri individu yang melibatkan seluruh bagian atau domain yang ada, domain tersebut meliputi domain kgonitif, afektif dan psikomotorik

Ini juga menunjukkan bahwa dalam teori humanistik, proses belajar dipandang bermuara pada manusia, teorinya mendekati dunia filsafat daripada dunia pendidikan itu sendiri. Dalam teori ini salah satu ide yang paling penting dalam pendidikan adalah bahwa siswa harus mempunyai kemampuan untuk mengarahkan sendiri perilakunya

\footnotetext{
Orientasi Baru).

${ }^{8}$ Iskandar.

${ }^{9}$ Iskandar.
} 
dalam belajar (self regulated learning), apa yang akan dipelajari dan sampai tingkatan mana, kapan, dan bagaimana siswa belajar daripada sekedar menjadi penerima pasif dalam proses belajar. ${ }^{10}$

Menurut teori humanistik, belajar adalah suatu proses transformasi nilai untuk memanusiakan manusia. ${ }^{11}$ Proses belajar dianggap berhasil jika si pelajar memahami lingkungannya dan dirinya sendiri. Siswa dalam proses belajarnya harus berusaha agar lambatlaun ia mampu mencapai aktualisasi diri dengan sebaik-baiknya. Teori belajar ini berusaha memahami perilaku belajar dari sudut pandang pelakunya, bukan dari sudut pandang pengamatnya.Tujuan utama para pendidik adalah membantu si siswa untuk mengembangkan dirinya, yaitu membantu masing-masing individu untuk mengenal diri mereka sendiri sebagai manusia yang unik dan membantu dalam mewujudkan potensi-potensi yang ada dalam diri mereka. Jadi dapat disimpulkan bahwa teori belajar humanistik memandang bahwa: ${ }^{12}$

a) Hasil pendidikan yang bersifat aktif merupakan fokus utamanya, belajar tentang cara- cara belajar dan meningkatkan kreativitas dan semua potensi peserta didik.

b) kemampuan peserta didik mengambil tanggung jawab dalam menentukan apa yang dipelajari dan menjadi individu yang mampu mengarahkan diri sendiri dan mandiri merupakan hasil belajarnya.

c) Pendekatan di bidang seni dan hasrat ingin tahu merupakan hal yang paling penting menurut aliran ini.

d) kurikulum standar, perencanaan pembelajaran, ujian, sertifikasi

142.

${ }^{10}$ Baharuddin, Teori Belajar dan Pembelajaran,

${ }^{11}$ Baharuddin, Pendidikan Humanistik (Konsep, Teori, dan Aplikasi Praksis dalam Dunia Pendidikan) (Yogyakarta: Ar-Ruzz Media, 2007), 15.

${ }^{12}$ Achmad Rifai, Tri Anni, dan Catharina, Psikologi Pendidikan (Semarang: Unnes Press, 2009). pendidik dan kewajiban hadir di sekolah kurang ditekankan dalam pendekatan humanistik.

e) Metode pembelajaran individual dan kelompok dikombanisakan dalam pendekatan humanistik ini, disini pendidik memiliki status kesetaraan dengan peserta didik.

f) Kebebasan peserta didik untuk tumbuh dan melindungi peserta didik dari tekanan keluarga dan masyarakat selalu dipelihara dalam pendekatan humanistik ini.

g) Penggunaan pendekatan humanistik dalam pendidikan akan memungkinkan peserta didik menjadi individu yang beraktualisasi diri.

Humanistik ini lebih bermaksud membentuk insane manusia yang memiliki komitmen humaniter sejati, yaitu insane manusia yang memiliki kesadaran, kebebasan, dan tanggungjawab sebagai insane manusia individual, namun juga tidak terlepas dari kebenaran faktualnya bahwa diri manusia itu hidup di tengah masyarakat, sehingga ia memiliki tanggung jawab moral kepada lingkungannya, berupa keterpanggilannya untuk mengabdikan dirinya demi kemaslahatan masyarakatnya. ${ }^{13}$ Pandangan dan pendapat beberapa tokoh utama teori humanistik, diantaranya adalah Abraham H. Maslow, Carl. R. Rogers dan Arthur Combs.

\section{Pendidikan Karakter}

Untuk mendukung perwujudan citacita pembangunan karakter sebagaimana diamanatkandalamPancasiladanPembukaan UUD 1945 serta mengatasi permasalahan kebangsaan saat ini, maka Pemerintah menjadikan pembangunan karakter sebagai salah satu program prioritas pembangunan nasional. Semangat itu secara implisit

${ }^{13}$ Baharuddin, Pendidikan Humanistik (Konsep, Teori, dan Aplikasi Praksis dalam Dunia Pendidikan), 22. 
ditegaskan dalam Rencana Pembangunan Jangka Panjang Nasional (RPJPN) tahun 2005-2025, di mana pendidikan karakter ditempatkan sebagai landasan untuk mewujudkan visi pembangunan nasional, yaitu "Mewujudkan masyarakat berakhlak mulia, bermoral, beretika, berbudaya, dan beradab berdasarkan falsafah Pancasila." (Panduan Pelaksanaan Pendidikan Karakter, Pusat Kurikulum dan Perbukuan, 2011: 5)

Terkait dengan upaya mewujudkan pendidikan karakter sebagaimana yang diamanatkan dalam RPJPN, sesungguhnya hal yang dimaksud itu sudah tertuang dalam fungsi dan tujuan pendidikan nasional, yaitu "Pendidikan nasional berfungsi mengembangkandanmembentukwatakserta peradaban bangsa yang bermartabat dalam rangka mencerdaskan kehidupan bangsa, bertujuan untuk berkembangnya potensi peserta didik agar menjadi manusia yang beriman dan bertakwa kepada Tuhan Yang Maha Esa, berakhlak mulia, sehat, berilmu, cakap, kreatif, mandiri, dan menjadi warga negara yang demokratis serta bertanggung jawab" (Sumber: Undang-undang Republik Indonesia Nomor 20 Tahun 2003 tentang Sistem Pendidikan Nasional --UUSPN) (Panduan Pelaksanaan Pendidikan Karakter, Pusat Kurikulum dan Perbukuan, 2011: 6).

Dengan demikian, RPJPN dan UUSPN merupakan landasan yang kokoh untuk melaksanakan secaraoperasional pendidikan budaya dan karakter bangsa sebagai prioritas program Kementerian Pendidikan Nasional 2010-2014, yang dituangkan dalam Rencana Aksi Nasional Pendidikan Karakter (2010): pendidikan karakter disebutkan sebagai pendidikan nilai, pendidikan budi pekerti, pendidikan moral, pendidikan watak yang bertujuan mengembangkan kemampuan seluruh warga sekolah untuk memberikan keputusan baik-buruk, keteladanan, memelihara apa yang baik \& mewujudkan kebaikan itu dalam kehidupan sehari-hari dengan sepenuh hati.
Atas dasar apa yang telah diungkapkan di atas, pendidikan karakter bukan hanya sekedar mengajarkan mana yang benar dan mana yang salah. Lebih dari itu, pendidikan karakter adalah usaha menanamkan kebiasaan-kebiasaan yang baik (habituation) sehingga peserta didik mampu bersikap dan bertindak berdasarkan nilai-nilai yang telah menjadi kepribadiannya. Dengan kata lain, pendidikan karakter yang baik harus melibatkan pengetahuan yang baik (moral knowing), perasaan yang baik atau loving good (moral feeling) dan perilaku yang baik (moral action) sehingga terbentuk perwujudan kesatuan perilaku dan sikap hidup peserta didik (Panduan Pelaksanaan Pendidikan Karakter, Pusat Kurikulum dan Perbukuan, 2011: 6).

\section{Metode Penelitian}

Jenis penelitian yang digunakan dalam penelitian ini adalah penelitian survey dengan pendekatan kualitatif. Penelitia survey digunakan karena peneliti bermaksud untuk mengetahui bagaimana hasil dari proses pembelajaran pendidikan karakter berbasis pendekatan humanistik. Penelitian survei, merupakan penelitian yang tidak memberikan perlakuan apapun kepada responden, hanya mengumpulkan data menggunakan instrumen yang telah dibakukan, seperti angket, tes dan lain sebagainya.

Menurut Cohen dan Nomion (1982) penelitianjenissurveyinimerupakankegiatan penelitian dengan mengumpulkan data pada saat tertentu dengan tujuan mendeskripsikan suatu keadaan, mengidentifikasi keadaan, dan menentukan suatu hubungan di antara kejadian yang spesifik. Ini senada dengan yang dikemukakan oleh Licoln dan Duba dalam Iskandar (2008:195) bahwa masalah penelitian survei perlu dibatasi melalui fokus penelitian karena adanya suatu penelitian yang tidak dimulai dari suatu yang vakum atau kosong tetapi 
berdasarkan persepsi seseorang terhadap masalah, penetapan fokus penelitian dapat membatasi apa yang ingin diteliti karena fenomena - fenomena yang terjadi bersifat holistik, fokus penelitian berfungsi untuk memenuhi kriteria suatu responden yang diperoleh di lapangan. Adapun yang menjadi pupolasi dalam penelitian ini adalah seluruh mahasiswa Pendidikan Guru Madrasah Ibtidaiyah UIN Antasari Banjarmasin yang telah mengambil mata kuliah Pendidikan Karakter dengan pendekatan humanistik. Sampel diambil dengan menggunakan teknik pengambilan sampel jenuh, yakni mengambil keseluruhan mahasiswa yang telah mengambil mata kuliah pendidikan karakter dengan pendekatan humanistik, yakni sebesar 72 orang mahasiswa. Instrumen yang digunakan dalam menghimpun data di penelitian ini berupa angket (kuesioner). Angket digunakan untuk memperoleh informasi terkait hasil implementasi pendekatan humanistik yang meneakankan pada proses pembelajaran yang dialami peserta didik dibandingkan hasil belajar, seperti: pemahaman mahasiswa akan tujuan belajar, partisipasi aktif mahasiswa dalam menumbuhkan nilai, mengembangkan potensi mahasiswa atas inisiatif sendiri, berfikir kritis, proses pemelajaran dilakukan secara mandiri, mengemukakan pendapat, memilih pilihannya sendiri, melakukkan apa yang diinginkan dan menanggung resiko perilaku yang ditunjukkan, merasa lebih berprestasi.

Setelah data dari angket dikumpulkan maupun dari dokumentasi, selnjutnya data dianalisis degan menggunakan analisis data statistik deskriptif (teknik prosentase/ deskriptif persentase) dari semua item pertanyaan yang diajukan dalam angket tersebut, yakni berupa frekuensi, persentase, dan rata-rata dengan cara mengklasifikasikan data. "Tahapan yang dilakukan dalam menganalisis data penelitian survei adalah (1) Memasukkan data ke dalam kartu pengolahan data (file data). (2) Membuat tabel frekuensi atau tabel silang. (3) Mengedit data. Teknis analisis statistik deskriptif yang digunakan dalam penelitian ini adalah melalui perhitungan mean atau rerata dan frekuensi. Selain itu, untuk memaparkan data digunakan visualisasinya dalam bentuk diagram atau table. $^{14}$ Analisa statistik deskriptif yang digunakan dalam penelitian berfungsi untuk mendeskripsikan atau memberi gambaran terhadap objek yang diteliti melalui data sampel atau populasi sebagaimana adanya, tanpa melakukan analisis dan membuat kesimpulan yang berlaku umum. ${ }^{15}$ Adapun Kriteria interpretasi data yang digunakan dalam penelitian ini adalah dengan mengasumsikan hasil prosentase terbanyak dari setiapitem pertanyaan sebagaigambaran hasil implementasi proses pembelajaran pada mata kuliah pendidikan karakter dengan pendekatan humanistik.

\section{Hasil Penemuan}

Jurusan Pendidikan Guru Madrasah Ibtidaiyah Universitas Islam Antasari Banjarmasin merumuskan mata kuliah PendidikanKarakter sebagai salah satu upaya yang dilakukan untuk mempersiapkan calon guru yang unggul kompetitif, dan berakhlak. Secara umum mata kuliah ini bertujuan agar mahasiswa mampu memperoleh pengetahuan tentang pendidikan karakter, membangun sikap dan perilaku berkarakter, serta mampu mengembangkan pembelajaran berbasis karakter pada pendidikan jenjang dasar. Secara khusus tujuan mata kuliah ini adalah agar mahasiswa mampu: (1) Memiliki pengetahuan tentang konsep dasar karakter dan pendidikan karakter; (2) Bersikap dan berperilaku secara berkarakter dalam kehidupan di kampus maupun di luar kampus; (3) Menguasai konsep dasar dan

${ }^{14}$ Masri Singarimbun, Metode Penelitian Survei (Jakarta: LP3ES, 1989), 8.

15 Sugiyono, Metode Penelitian Kuantitatif, Kualitatif dan RED (Bandung: Alfabet, 2009), 29. 
pola pengembangan pembelajaran berbasis pendidikan karakter; (4) Menguasai konsep dasar dan pola pengembangan pendidikan karakter di sekolah; (5) Menguasai konsep dan pola pengembangan pendidikan karakter di masyarakat; (6) Menguasai konsep dasar dan pola pengembangan penilaian otentik karakter. Perkuliahan dilaksanakan dengan pendekatan humanistik dengan berbagai metode dan strategi pembelajaran di mana ilustrasi dari perkuliahan pendekatan humanistik dapat terlihat dalam tabel berikut:

Tabel 1 Aktivitas Pembelajaran Pendidikan Karakter Berbasis Pendekatan Humanistik

\begin{tabular}{|c|c|c|c|}
\hline No. & $\begin{array}{c}\text { Penguassan } \\
\text { Konsep }\end{array}$ & $\begin{array}{l}\text { Aktivasi } \\
\text { Nilai }\end{array}$ & $\begin{array}{c}\text { Nilai yang } \\
\text { diharapkan } \\
\text { Muncul }\end{array}$ \\
\hline 1 & $\begin{array}{l}\text { 1. Konsep Dasar } \\
\text { Karakter } \\
\text { 2. Dimensi- } \\
\text { dimensi } \\
\text { Karakter yang } \\
\text { Baik }\end{array}$ & $\begin{array}{l}\text { Pengala- } \\
\text { man Nilai } \\
\text { dan evaluasi } \\
\text { wal nilai } \\
\text { diri }\end{array}$ & \begin{tabular}{|l|} 
Religius, \\
Jujur, Kerja \\
Keras, \\
Kreatif, \\
Mandiri, \\
Menghargai \\
Prestasi, \\
Bersahabat/ \\
Komunikatif \\
\end{tabular} \\
\hline 2 & $\begin{array}{l}\text { 1. Pengertian } \\
\text { Pendidikan } \\
\text { Karakter } \\
\text { 2. Tujuan } \\
\text { Pendidikan } \\
\text { Karakter } \\
\text { 3. Saluran-saluran } \\
\text { Pendidikan } \\
\text { Karakter } \\
\text { 4. Materi Kajian } \\
\text { Karakter }\end{array}$ & $\begin{array}{l}\text { Aku Sangat } \\
\text { Bangga } \\
\text { Menjadi } \\
\text { Diriku } \\
\text { Sendiri }\end{array}$ & $\begin{array}{l}\text { Religius, } \\
\text { Jujur, Kerja } \\
\text { Keras, } \\
\text { Kreatif, } \\
\text { Mandiri, } \\
\text { Menghargai } \\
\text { Prestasi, } \\
\text { Bersahabat/ } \\
\text { Komunikatif, } \\
\text { Tanggung } \\
\text { Jawab }\end{array}$ \\
\hline 3 & $\begin{array}{l}\text { Tinjauan } \\
\text { Islam tentang } \\
\text { Pendidikan } \\
\text { Karakte }\end{array}$ & $\begin{array}{l}\text { Screening } \\
\text { Movie Dan } \\
\text { Analisis } \\
\text { Nilai } \\
\text { Short Movie } \\
\text { Competition }\end{array}$ & $\begin{array}{l}\text { Tanggung } \\
\text { Jawab, } \\
\text { Kerja Keras, } \\
\text { Disiplin, Rasa } \\
\text { Ingin Tahu }\end{array}$ \\
\hline
\end{tabular}

\begin{tabular}{|c|c|c|c|}
\hline 4 & $\begin{array}{l}\text { 1. Membangun } \\
\text { Ikatan dan } \\
\text { Model Karakter } \\
\text { 2. Guru sebagai } \\
\text { Model Karakter }\end{array}$ & $\begin{array}{l}\text { Antara } \\
\text { Curiga dan } \\
\text { Prasangka }\end{array}$ & $\begin{array}{l}\text { Cinta Damai, } \\
\text { Peduli Sosial, } \\
\text { Bersahabat/ } \\
\text { Komunikatif, } \\
\text { Semangat } \\
\text { Kebangsaan, } \\
\text { Demokratis, } \\
\text { Cinta Tanah } \\
\text { Air, Toleransi }\end{array}$ \\
\hline 5 & $\begin{array}{l}\text { 1. Membangun } \\
\text { Disiplin Kelas } \\
\text { Berbasis } \\
\text { Karakter } \\
\text { 2. Membangun } \\
\text { Interaksi } \\
\text { Kelas Berbasis } \\
\text { karakter } \\
\text { 3. Membangun } \\
\text { Kepedulian / } \\
\text { Kerjasama } \\
\text { Kelas Berbasis } \\
\text { Karakter }\end{array}$ & $\begin{array}{l}\text { Tidak } \\
\text { Sombong } \\
\text { Dan Tidak } \\
\text { Minder }\end{array}$ & $\begin{array}{l}\text { Cinta } \\
\text { Damai, Jujur, } \\
\text { Toleransi, } \\
\text { Demokratis, } \\
\text { Semangat } \\
\text { Kebangsaan, } \\
\text { Cinta Tanah } \\
\text { Air, Peduli } \\
\text { Lingkungan, } \\
\text { Peduli Sosial }\end{array}$ \\
\hline 6 & $\begin{array}{l}\text { 1. Kurikulum dan } \\
\text { Pendidikan } \\
\text { Karakter } \\
\text { 2. B. Desain } \\
\text { Sistem/Proses } \\
\text { Pembelajaran } \\
\text { dan Pendidikan } \\
\text { Karakter }\end{array}$ & $\begin{array}{l}\text { Review nilai } \\
\text { karakter } \\
\text { dalam novel }\end{array}$ & $\begin{array}{l}\text { Rasa Ingin } \\
\text { Tahu, Kreatif, } \\
\text { Disiplin, } \\
\text { Gemar } \\
\text { Membaca }\end{array}$ \\
\hline 7 & $\begin{array}{l}\text { 3. C. Membangun } \\
\text { Pembelajaran } \\
\text { Berbasis } \\
\text { Karakter } \\
\text { 4. D. Strategi } \\
\text { Mengem- } \\
\text { bangkan } \\
\text { Pembelajaran } \\
\text { Berbasis } \\
\text { Karakter } \\
\end{array}$ & $\begin{array}{l}\text { Resolusi } \\
\text { Konflik }\end{array}$ & $\begin{array}{l}\text { Cinta } \\
\text { Damai, Jujur, } \\
\text { Toleransi, } \\
\text { Demokratis, } \\
\text { Semangat } \\
\text { Kebangsaan, } \\
\text { Cinta Tanah } \\
\text { Air, Peduli } \\
\text { Lingkungan, } \\
\text { Peduli Sosial } \\
\end{array}$ \\
\hline 8 & $\begin{array}{l}\text { Tertulis kegiatan } \\
\text { eksplorasi nilai- } \\
\text { aktivasi nilai }\end{array}$ & & \\
\hline 9 & $\begin{array}{ll}\text { 1. } & \text { Hakikat } \\
& \text { Sekolah } \\
& \text { Berkarakter } \\
\text { 2. } & \text { Nilai } \\
& \text { Karakter yang } \\
\text { Dikembang- } \\
\text { kan di Sekolah } \\
\text { 3. Membangun } \\
\text { Budaya Moral } \\
\text { di Sekolah }\end{array}$ & $\begin{array}{l}\text { Gali } \\
\text { Kepribadian }\end{array}$ & $\begin{array}{l}\text { Religius, } \\
\text { Jujur, Kerja } \\
\text { Keras, } \\
\text { Kreatif, } \\
\text { Mandiri, } \\
\text { Menghargai } \\
\text { Prestasi, } \\
\text { Bersahabat/ } \\
\text { Komunikatif, } \\
\text { Cinta Damai, } \\
\text { Peduli Sosial, } \\
\text { Tanggung } \\
\text { Jawab, Rasa } \\
\text { Ingin Tahu }\end{array}$ \\
\hline
\end{tabular}




\begin{tabular}{|c|c|c|c|}
\hline 10 & $\begin{array}{l}\text { 1. Membangun } \\
\text { Sekolah } \\
\text { Demokratis } \\
\text { 2. Membangun } \\
\text { Sekolah } \\
\text { Berdisiplin }\end{array}$ & $\begin{array}{l}\text { Tokoh } \\
\text { Inspiratif }\end{array}$ & $\begin{array}{l}\text { Religius, } \\
\text { Jujur, Kerja } \\
\text { Keras, } \\
\text { Kreatif, } \\
\text { Mandiri, } \\
\text { Menghargai } \\
\text { Prestasi, } \\
\text { Bersahabat/ } \\
\text { Komunikatif, } \\
\text { Cinta Damai, } \\
\text { Peduli Sosial, } \\
\text { Tanggung } \\
\text { Jawab, } \\
\text { Rasa Ingin } \\
\text { Tahu, Cinta } \\
\text { Tanah Air, } \\
\text { Semangat } \\
\text { Kebangsaan }\end{array}$ \\
\hline 11 & $\begin{array}{ll}\text { 3. Moral } \\
\text { Membangun } \\
\text { Sekolah } \\
\text { Kooperatif } \\
\text { 4. Membangun } \\
\text { Sekolah } \\
\text { Progresif } \\
\text { Berbasis } \\
\text { Karakter }\end{array}$ & $\begin{array}{l}\text { Inspirasi } \\
\text { Hidup }\end{array}$ & $\begin{array}{l}\text { Religius, } \\
\text { Jujur, Kerja } \\
\text { Keras, } \\
\text { Kreatif, } \\
\text { Mandiri, } \\
\text { Menghargai } \\
\text { Prestasi, } \\
\text { Bersahabat/ } \\
\text { Komunikatif, } \\
\text { Cinta Damai, } \\
\text { Peduli Sosial, } \\
\text { Tanggung } \\
\text { Jawab, Rasa } \\
\text { Ingin Tahu } \\
\end{array}$ \\
\hline 12 & $\begin{array}{l}\text { 1. Strategi } \\
\text { Mendidik Anak } \\
\text { Berkarakter di } \\
\text { Sekolah } \\
\text { 2. Membangun } \\
\text { Kemitraan } \\
\text { Sekolah } \\
\text { dan Orang } \\
\text { Tua dalam } \\
\text { Pengembangan } \\
\text { Karakter Anak } \\
\text { 3. Strategi } \\
\text { Pemberdayaan } \\
\text { Keluarga bagi } \\
\text { Pendidikan } \\
\text { Karakter Anak }\end{array}$ & $\begin{array}{l}\text { Nilai } \\
\text { Kehidupan }\end{array}$ & $\begin{array}{l}\text { Religius, } \\
\text { Jujur, Kerja } \\
\text { Keras, } \\
\text { Kreatif, } \\
\text { Mandiri, } \\
\text { Menghargai } \\
\text { Prestasi, } \\
\text { Bersahabat/ } \\
\text { Komunikatif, } \\
\text { Cinta Damai, } \\
\text { Peduli Sosial, } \\
\text { Tanggung } \\
\text { Jawab, Rasa } \\
\text { Ingin Tahu }\end{array}$ \\
\hline
\end{tabular}

\begin{tabular}{|c|c|c|c|}
\hline 13 & $\begin{array}{l}\text { 1. Konsep Dasar } \\
\text { Masyarakat } \\
\text { Berkarakter } \\
\text { 2. Strategi } \\
\text { Membangun } \\
\text { Masyarakat } \\
\text { Berkarakter }\end{array}$ & Biografiku & $\begin{array}{l}\text { Religius, } \\
\text { Jujur, Kerja } \\
\text { Keras, } \\
\text { Kreatif, } \\
\text { Mandiri, } \\
\text { Menghargai } \\
\text { Prestasi, } \\
\text { Bersahabat/ } \\
\text { Komunikatif, } \\
\text { Cinta Damai, } \\
\text { Peduli Sosial, } \\
\text { Tanggung } \\
\text { Jawab, Rasa } \\
\text { Ingin Tahu }\end{array}$ \\
\hline 14 & $\begin{array}{l}\text { 1. Konsep Dasar } \\
\text { Penilaian } \\
\text { Otentik } \\
\text { 2. Bisakah } \\
\text { Karakter } \\
\text { Anak Diukur/ } \\
\text { Dinilia? }\end{array}$ & Kejujuran & $\begin{array}{l}\text { Religius, } \\
\text { Jujur, Kerja } \\
\text { Keras, } \\
\text { Kreatif, } \\
\text { Mandiri, } \\
\text { Menghargai } \\
\text { Prestasi, } \\
\text { Bersahabat/ } \\
\text { Komunikatif, } \\
\text { Cinta Damai, } \\
\text { Peduli Sosial, } \\
\text { Tanggung } \\
\text { Jawab, Rasa } \\
\text { Ingin Tahu }\end{array}$ \\
\hline 15 & $\begin{array}{l}\text { 3. Strategi } \\
\text { Pengembangan } \\
\text { Penilaian } \\
\text { Karakter } \\
\text { Berbasis } \\
\text { Penilaian } \\
\text { Otentik } \\
\text { 4. Mengembang- } \\
\text { kan Model } \\
\text { Penilaian } \\
\text { Karakter } \\
\text { Berbasis } \\
\text { Penilaian } \\
\text { Otentik }\end{array}$ & Maafkan & $\begin{array}{l}\text { Religius, } \\
\text { Jujur, Kerja } \\
\text { Keras, } \\
\text { Kreatif, } \\
\text { Mandiri, } \\
\text { Menghargai } \\
\text { Prestasi, } \\
\text { Bersahabat/ } \\
\text { Komunikatif, } \\
\text { Cinta Damai, } \\
\text { Peduli Sosial, } \\
\text { Tanggung } \\
\text { Jawab, Rasa } \\
\text { Ingin Tahu }\end{array}$ \\
\hline 16 & $\begin{array}{l}\text { Proyek Nilai: } \\
\text { Short Movie } \\
\text { Festival }\end{array}$ & & $\begin{array}{l}\text { Religius, } \\
\text { Jujur, Kerja } \\
\text { Keras, } \\
\text { Kreatif, } \\
\text { Mandiri, } \\
\text { Menghargai } \\
\text { Prestasi, } \\
\text { Bersahabat/ } \\
\text { Komunikatif, } \\
\text { Peduli Sosial, } \\
\text { Tanggung } \\
\text { Jawab, Rasa } \\
\text { Ingin Tahu }\end{array}$ \\
\hline
\end{tabular}


Berdasarkan tabel di atas, diketahui bahwa implementasi proses pembelajaran dalam mata kuliah pendidikan karakter di Jurusan Pendidikan Guru Madrasah Ibtidaiyah Universitas Islam Negeri Antasari Banjarmasin menekankan tiga domain, yakni kognitif, afektif dan psikomotor. Ini artinya, dalam proses pembelajarannya, mata kuliah pendidikan karakter telah berupaya memfokuskan proses pembelajaran yang bermuara pada kebutuhan manusia, sebagai satu individu.

Mahasiswa, selama mengikuti proses pembelajaran, diarahkan untuk memiliki dan mengembangkan kemampuannya sendiri, dan mengarahkan perilaku belajar secara teratur. Selain itu, dalam perkuliahan, terlihat pola di mana mahasiswa dilibatkan sepenuhnya dalam pelaksanaan proses pembelajaran, seperti mengerjakan tugastugas dan projek-projek nilai. Proses pembelajaran pendidikan karakter yang dilaksanakan berhasil mencapai tujuannya, yakni menjadikan mahasiswa yang mengikuti perkuliahan tersebut mengetahui dan menyadari dirinya sebagai suatu proses pertumbuhan dan pengembangan diri yang sedang dan akan terus berubah, selain itu mahasiswa dengan otomatis mencari jati diri dan mengenal konsep dan identitas dirinya masing-masing. Di satu sisi, perkuliahan ini telah dirancang sedemikian rupa sehingga hasil belajar mahasiswa menjadi keterpaduan yang pas, di mana, selain mahasiswa memahami konsep konsep secara menyeluruh, mereka secara alamiah juga mengembangkan potensi dalam diriya, menumbuhkan kesadaran hati dan pikiran mereka akan nilai agar menjadi selaras dan sejalan. Ini semua merupakan bagian konsep dari pembelajaran berbasis pendekatan humanistik.

Dari hasil survey diketahui bahwa dengan desain perkuliahan pendidikan karakter berbasis pendekatan humanistik yang telah dirancang sebelumnya, secara general, diketahui bahwa ada peningkatan nilai dan sikap berbasis humanistik dalam diri mahasiswa sebesar $40 \%$. Ini diketahui dari selama 16 kali proses pemelajaran, 75\% mahasiswa menyatakan bahwa mereka merasa telah mengalami perkembangan nilai dalam dirinya dan perubahan sikap. Yakni ditandai dengan adanya fakta bahwa mahasiswa mengganti konsep nilai khusus dengan konsep nilai umum, yang kaitannya dengan moral. Dalam proses pembelajaran mahasiswa telah merumuskan secara individu konsep nilai yang berdampak pada moral dan sikapnya yang baru dan ini dikembangkannya ke dalam kode perilakunya.Selain itu, merekajuga meyakini dan melakukan pengendalian terhadap perilaku sendiri.

Dari hasil survey juga diketahui bahwa 80\% mahasiswa merasa bahwa masisngmasing dirinya mengenal diri mereka sendiri lebih dalam dari sebelumnya, dan $87 \%$ merasa bahwa mereka memiliki tujuan hidup yang lebih jelas, dan $89 \%$ menyatakan bahwa potensi di dalam dirinya lebih bisa dieksporasi lebih dalam setelah ada kegiatan project nilai. Proses pembelajaran ini telah membuat mahasiswa menyadari apa saja yang mereka inginkan dalam hidup mereka, dan mengenal indikasi kebahagiaan hidup mereka yang berdampak pada pencapaian potensi dan prestasi hidupnya. Selama proses pembelajaran, mahasiswa diperkenalkan dengan impian, cita, dan nilai hidup sebagai tujuan hidup mereka dan seberapa besar upaya yang mereka lakukan untuk mencapai atau bagaimana cara mereka mencapainya. Selain itu, mahasiswa juga mendalami diri mereka sendiri dengan mengenali potensi diri mereka sendiri dan merumuskan upaya yang dilakukan untuk memperbesar pengaruh dari potensi yang dimilikinya. Mereka juga dikenalkan dengan konsep memaafkan diri sendiri dan menyukuri keberadaan hidupnya. Semua aktivtas dan project yang telah diberikan kepada mahasiswa 
menunjukkan adanya perubahan yang terjadi dari sikap mahasiswa.Semua aktivitas tersebut merupakan bagian dari pendekatan pembelajaran humanistik yang diterapkan dalam mata kuliah pendidikan karakter.

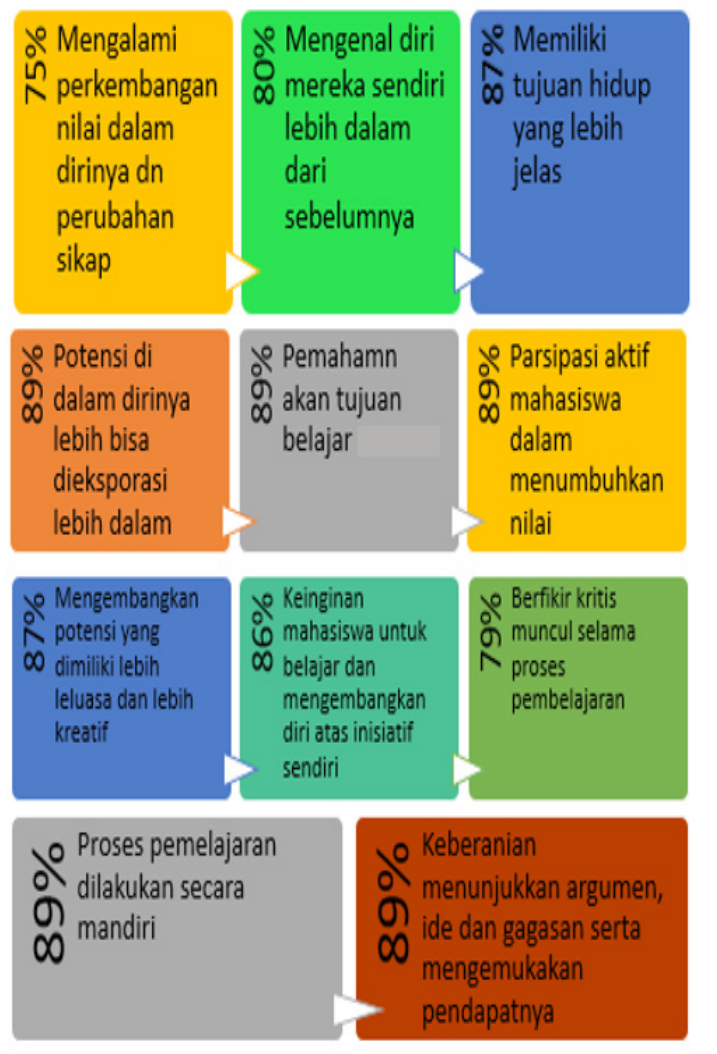

Gambar 1 Diagram hasil implementasi proses pembelajaran pendidikan karakter dengan pendekatan humanistiK

Dari hasil survey yang digambarkan di atas juga diketahui bahwa pemahaman mahasiswa akan tujuan belajar sebesar $89 \%$, mahasiswa lebih terlibat dalam proses pembelajaran ini ditunjukkan dengan partisipasi aktif mahasiswa dalam menumbuhkan nilai sebesar $89 \%$. Mahasiswa mengenal tujuan proses pembelajaran dan memberikan respon positif dalam setiap proses pembelajaran, ini merupakan salah satu indikator dari aktifnya mahasiswa daalm proses. Selain itu, memiliki rasa ingin tahu yang tinggi akan topik yang dibahas dan mengerjakan setiap project yang diberikan dosen. Mahasiswa juga menambahkan pegetahuannya dengan membaca dan tertarik dengan setiap topik yang dibicarakan dalam proses pembelajaran pendidikan karakter berbasis pendekatan humanistik ini. Mahasiswa juga mengembangkan potensi yang dimiliki lebih leluasa dan lebih kreatif dengan angka persentase sebesar $87 \%$ selama proses pembelajaran dan keinginan mahasiswa untuk belajar dan mengembangkan diri atas inisiatif sendiri sebesar $86 \%$, berfikir kritis muncul selama proses pembelajaran sebesar 79\%, mahasiswa menunjukkan sikap kritisnya dengan menyampaikan kritiknya terhadap topik dan ataupun dalam pembahasan materi yang disampaikan, mahasiswa menunjukkan sikap bertaya dan kritis karena mtelah membaca mataerimateri dan menguasainya. Selain itu, juga proses pemelajaran yang dilakukan secara mandiri sebesar 89\%, menurut Gibbons (2002) kemandirian dalam proses belajar sangat erkaitan degan metacognition, yakni pemikiran setiap individu mengenai pikirannya, memikirkan apa yang diketahui, apa yang dilakukan, dan apa yang dipikirkan, sedangkan Hacker, Dunlosky, dan Graesser (1998) berpendapat bahwa metacognition akan fokus terhadap pemahaman individu mengenai regulasi dirinya, dan menjadi bagian penting dalam pwmikiran. Selain itu, dalam proses pembelajaran pendidikan karakter berbasis pendekatan humanistik, mahasiswa terlihat memiliki keinginan yang kuat untuk menyelesaikan project dan mencapai tujuan pembelajaran, mereka juga cenderung memberikan pendapat, berperilaku atas kehendak sendiri, ulet, tekun, bertindak secara kreatif, penuh inisiatif dan berupaya untuk maju, dan bergerak tanpa mengharapkan bimbingan dari dosen ataupun kawannya. 


\section{Tabel 1 Perbandingan Nilai Persentase \\ Kegiatan Proses Pembelajaran \\ Pendidikan Karakter Berbasis Pendekatan Humanistik}

\begin{tabular}{|c|l|c|c|}
\hline No. & \multicolumn{1}{|c|}{ Indikator } & M1 & M2 \\
\hline 1 & $\begin{array}{l}\text { Perkembangan nilai dan } \\
\text { perubahan sikap }\end{array}$ & $35 \%$ & $75 \%$ \\
\hline 2 & $\begin{array}{l}\text { Mengenal diri lebih dalam } \\
\text { dari sebelumnya }\end{array}$ & $45 \%$ & $80 \%$ \\
\hline 3 & $\begin{array}{l}\text { Tujuan hidup yang lebih } \\
\text { jelas }\end{array}$ & $52 \%$ & $87 \%$ \\
\hline 4 & $\begin{array}{l}\text { Potensi di dalam dirinya } \\
\text { lebih bisa dieksporasi lebih } \\
\text { dalam }\end{array}$ & $58 \%$ & $89 \%$ \\
\hline 5 & $\begin{array}{l}\text { Pemahaman akan tujuan } \\
\text { belajar }\end{array}$ & $56 \%$ & $89 \%$ \\
\hline 6 & $\begin{array}{l}\text { Parsipasi aktif dalam } \\
\text { menumbuhkan nilai }\end{array}$ & $57 \%$ & $89 \%$ \\
\hline 7 & $\begin{array}{l}\text { Mengembangkan potensi } \\
\text { yang dimiliki lebih leluasa } \\
\text { dan lebih kreatif }\end{array}$ & $58 \%$ & $87 \%$ \\
\hline 8 & $\begin{array}{l}\text { Keinginan untuk belajar } \\
\text { dan mengembangkan diri } \\
\text { atas inisiatif sendiri }\end{array}$ & $63 \%$ & $86 \%$ \\
\hline 9 & $\begin{array}{l}\text { Berfikir kritis muncul } \\
\text { selama proses } \\
\text { pembelajaran }\end{array}$ & $48 \%$ & $79 \%$ \\
\hline 10 & $\begin{array}{l}\text { Proses pemelajaran } \\
\text { dilakukan secara mandiri }\end{array}$ & $46 \%$ & $89 \%$ \\
\hline 11 & $\begin{array}{l}\text { Keberanian menunjukkan } \\
\text { argumen, ide dan gagasan } \\
\text { serta mengemukakan } \\
\text { pendapatnya }\end{array}$ & $42 \%$ & $89 \%$ \\
\hline
\end{tabular}

Mahasiswa juga berani menunjukkan argumen, ide dan gagasan serta mengemukakan pendapatnya sebesar $89 \%$, mereka memilih pilihannya sendiri dalam mengerjakan projek dan aktivasi nilai dan menunjukkan idenya, mereka melakukkan apa yang diinginkan dan menanggung resiko perilaku yang ditunjukkan dengan mengemukakan pendapatnya, merekaberprestasi dalam pelaksanaan project nilai. Sekali lagi, persentase secara keseluruhan proses pembelajaran pendidikan karakter berbasis pendekatan humanistik, dengan bobot persentase $35-63 \%$ menjadi $75 \%-89 \%$, telah mampu meningkatkan nilai dan potensi diri mahasiswa.
Prosespembelajaran pendidikan karakter berbasis pendekatan humanistik telah berhasil memahami perilaku belajar mahasiswa dari sudut pandang pelakunya, artinya bukan sudut pandang dosen sebagai pengamat. Dalam prosesnya mahasiswa mampu mengenali diri mereka sendiri sebagai manusia yang unik dan spesial, yang mana ini membantu mereka mewujudkan potensi-potensi yang ada dalam diri mereka. Impelementasi proses pembelajaran dengan pendekatan humanistik terlihat lebih penuh spirit dan ruhnya selama proses pembelajaran ditandai dengan mana warna-warni metode pembelajaran yang digunakan. Dalam prosesnya, dosen menjadi fasilitator bagi mahasiswa, dosen memberikan motivasi dan kesadaran akan makna belajar itu sendiri dalam kehidupan. Dosen berhasil memberikan fasilitas pengalamanbelajarbagi mahasiswa sehingga mereka memperoleh tujuan proses pembelajaran. Selama pendekatan humanistik diimplementasikan, mahasiswa sebagai pelaku utama kegiatan pembelajaran (student center) memaknai proses pengalaman belajarnya sendiri. Pada akhirnya, mahasiswa memahami potensi dalam dirinya, mengembangkan potensi tersebut secara positif dan meminimalkan nilai negatif dengan keberadaan potensi yang dimilikiya.

\section{Kesimpulan dan Saran}

Berdasarkan hasil penelitian diketahui dengan desain perkuliahan pendidikan karakter berbasis pendekatan humanistik yang telah dirancanng sebelumnya, diketahui bahwa dalam 16 kali proses pemelajaran, $75 \%$ mahasiswa merasa telah mengalami perkembangan nilai dalam dirinya, 80\% merasa bahwa masisng-masing dirinya mengenal diri mereka sendiri lebih dalam dari sebelumnya, dan $87 \%$ merasa bahwa mereka memiliki tujuan hidup yang lebih jelas, dan $89 \%$ menyatakan bahwa potensi di dalam dirinya lebih bisa dieksporasi 
lebih dalam setelah ada kegiatan project nilai. Secara general, ada peningkatan nilai dan sikap berbasis umanistik dalam diri mahasiswa sebesar $40 \%$, menjadi $75 \%$ $89 \%$, di mana sebelumnya hanya berada pada nilai persetase $35-63 \%$. Itu artinya, pendekatan humanistik dapat dijadikan salah satu pilihan pendekatan dalam proses pembelajaran yang berkaitan dengan proses pembelajaran yang menekankan pada tiga domain, ognitif, afektif, da psikomotor.

Penelitian ini masih sangat terbatas pada implementasi dalam kasus tertentu dan kondisi terbatas, diharapkan untuk peneliti berikutnya untuk dapat melanjutkan atau mengembangkan penelitian ini agar perubahan aspek kognitif, afektif dan psikomotor mahasiswa dalam mata kuliah yangserupadapatdiukur dengan pendekatan kuantitatif. Hal ini bertujuan untuk melihat pengaruh proses pembelajaran pendidikan karakter dengan pendekatan humanistik terhadap ketiga aspek belajar mahasiswa, sehingga dapat diilutrasikan dengan tepat pengaruh atau pun hubungan keduanya.

\section{Daftar Pustaka}

Abraham H. Maslow. Motivasi Dan Keperibadian. Jakarta: Pustaka Binoman Pressido, 1984.

Achmad Rifai, Tri Anni, dan Catharina. Psikologi Pendidikan. Semarang: Unnes Press, 2009.

Baharuddin. Pendidikan Humanistik (Konsep, Teori, dan Aplikasi Praksis dalam Dunia Pendidikan). Yogyakarta: Ar-Ruzz Media, 2007. . Teori Belajar dan Pembelajaran. V. Yogyakarta: Ar-Ruzz Media, 2010.

Iskandar. Psikologi Pendidikan (Sebuah Orientasi Baru). Ciputat: Gaung Persada Press, 2009.

M. Ngalim Purwanto. Psikologi Pendidikan. 16 ed. Bandung: Remaja Rosdakarya,
2000.

Masri Singarimbun. Metode Penelitian Survei. Jakarta: LP3ES, 1989.

Oemar Hamalik. Proses Belajar Mengajar. 6 ed. Jakarta: Bumi Aksara, 2007.

Sugiyono. Metode Penelitian Kuantitatif, Kualitatif dan RED. Bandung: Alfabet, 2009. 
138| Illementitiry Vol. 4 Edisi Juli-Desember 2018

Halaman ini bukan sengaja untuk dikosongkan 